were read on the therapeutic value of digestive ferment. Trials with the different preparations found in trade showed that nearly all German preparations were inert, while the only English preparation which was tested gave satisfactory results. Professor Kussmaul, finding that pepsine was always present in the gastric juice, even in very inveterate cases of gastric catarrh, does not believe that the administration of pepsine can be of much use. None of the speakers and experimentators seem to have attacked the subject from the practical point of view, such as has recently been done by Dr. William Roberts, of Manchester, who succeeded in completely peptonising milk with properly prepared pancreas extract, and who has thus opened out quite a new line of treatment for gastric disturbances. Pancreatic digestion is evidently beginning to interest the therapeutists as well as the physiologists. I must, however, reluctantly pass over the other papers read in this section for fear of making this letter too long.

I beg to call the attention of some of your readers to a paper read by Dr. Wyss, of Zurich, on Fœial Rickets, a subgect but too little studied in this country.

On coming to the Gynæcological section, in the debates of which, besides the most noted German professors, Mr. Spencer Wells (whose presence was felt by all as a high honour done to the Association) took an active part, I find the material much too overwhelming to give anything like a résumé in a letter like this. Amongst the more important papers I will only mention the following :-On Castration, by Professor Hegar (42 cases, with a mortality of 16.69 per cent. ; the cases operated on wene chiefly tumours of the uterus oophoritis, parametritis, \&c.) On Extirpation of Abdominal Tumours, by Schröder, and which subject gave rise to a very interesting discussion on Hydatid Tumours in the Female Pelvis, by Professor Freund.

In one of the general meetings it was decided that in future ladies should be entitled to receive only ladies' tickets, with a view of preventing them from reading papers or taking part in the discussions. This step was taken owing to the fact that last year an English lady read a paper in the Anatomical section. It was further decided to hold the next meeting at Dantzig.

Baden Baden, September 28th.

\title{
THE MURCHISON MEMORIAL.
}

Fifth List of Subscriptions.

\begin{tabular}{cc|}
$f$ & $s$. \\
1 & 1
\end{tabular}

Dr. Siddall (Clifton) ... Erasmus Wilson, Esq. Dr. Robert Elliot ..... Dr. Wilberforce Smith Dr. C. Holman (Reigate)

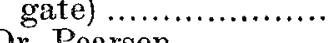

Dr. Pearson

Dr. Granville Bantock

Wm. Scott, Esq.

Dr. R. Brisco Owen (Beaumaris) ........

Dr. Withers Moore (Brighton) ............ Dr. W. Hardman Dr. W. Vawdrey Lush (Weymouth) ........

Joseph Prestwich, Esq. (Oxford)

Professor Fraser (Edin.

Jurgh) ................ Esq. (Ladvbrook)

Dr. Noel Gueneau de Dr. W. Arding (Wallingford)

Dr. C. J. B. Williams

Dr. Allfrey (St. Mary Cray)

A. Campbell Swinton. Esq., LL.D. (Kinnexghene)

Professor Acland (Oxford)
Dr. Douglas Powell ...

$2 \quad 2$ Dr. W. C. Coles

11 (Bourton - on - the-

J. W. Hulke, Esq.

11 F.R.C.S.,............

\begin{tabular}{ll|l}
1 & 1 & Dr. Clegg (Epping) ... \\
2 & 2 & Professor de Chaumont
\end{tabular}

$2 \quad 2$ (Netley)

Dr. Branfoot, A.M. M.

11 (Madras)

Professor Aitken (Net-

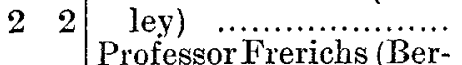

$22 \begin{array}{r}\text { Professor } \\ \operatorname{lin}) \ldots \ldots \ldots \ldots \ldots \ldots \ldots \ldots \ldots \ldots\end{array}$

Professors of the Cal-

11 cutta Medical Col-

lege, per Dr. David $1212 \underset{\text { Biz. :- }}{\text { B. Smith, Principal } 33}$

22 Dr. D. B. Smith.

5 S. B. Partridge, Esq.,

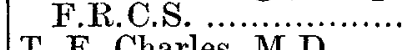

$3 \quad 3$ R. C. Chandra, Esq....... J. M. Coates, M.D. ......

11 H. Cayley, Esq

33 K. Macleod, A.M., M. D. S. C. Mackenzie, M.D. 1 I J. F.P. M'Connell, M.B. J. Anderson, M.D., F.R.S.

s.

11

11

55

1

11

11

11

11

30

339

50

32

50

16

32

$3 \quad 3$ D. D. Cunningham, M.....

C. H. Wood, Esq., F.C.S. 22 W. T. Woods, Esq. .....

\section{COarestondence.}

"Audi alteram partem."

STAPHYLORAPHY.

To the Editor of THE LANCET.

SIR,-In a communication by Dr. John Duncan in your last week's issue, styled "An Improvement in Staphy. loraphy," the author deplores the "considerable proportion of failures in staphyloraphy," and ascribes this want of success largely to the fact that no attempt is made to detach the velum palati from its connexion, by muco-periosteum, with the flow of the posterior nares.

Dr. Duncan advises the complete separation of the soft palate from this connexion by means of a bistoury, and quotes a case where he put the plan into practice, concluding with the remark that his single case does no more than prove the operation to be practicable.

I can assure Dr. Duncan, from an experience of a hundred or more operations, that the proceeding he recommends is not only practicable, but, among other things, essential to the attainment of any high degree of success, and that if he will modify his practice in the direction he himself indicates he will be less disposed to take a gloomy view of the proguosis in staphyloraphy. Perhaps I may venture to refer him to the seventh volume of St. Bartholomew's Hospital Reports, published 1871, where, if he is interested in the matter, he will find an exact description of the modifications he proposes. In the paper to which I refer the necessity of the detachment of the velum from the posterior margin of the hard palate is insisted on, and curved scissors are recommended for the purpose, while the use of a supplementary suture in certain cases is recommended.

I am, Sir, \&c.,

Stratford-place, w., Oct. 7th, 1879.

Thomas Smith.

\section{HONOURS TO MILITARY MEDICAL OFFICERS.}

To the Editor of THE LANCET.

SrR, - I have just been reading a book, published by Rivington and Co. last year-"Constantinople: How we got there. By an Engineer." In this work a passage occurs which strikingly confirms all you have written in THE LANCET, particularly in a leader of the 27th ultimo, concerning the shameful paucity of honour and rewards meted out to the Medical Department of the Army for their service in war, to say nothing of the insult offered to the profession by the Indian Viceroy, in being coupled with the telegraph and postal departments in his thanks to those engaged in the late Afghan war. When the neglect to bestow honours on the Department is so patent as to attract the notice of a layman, it is high time the profession in. terested should take some active steps to remedy the grierance. The author describing his visit to the English cemetery at Scutari, where many of the Crimean men are buried, says :- "One thing that struck us particularly at the cemetery was the number of graves on which the tomb. stone told that a doctor lay beneath. Let those who think that the path of a medical man is as devoid of danger as of glory go to those Eastern tombs and read the oft-told tale, not once nor thrice, but by scores of times, "Died in the execution of his duty,' and think of those awful periods when, though the war may be at its height, wounds form but the smallest portion of the danger; when cholera and fever stalk in their deadly strength through the crowded wards ; when appliances and comforts to meet these ghastly foes are nearly wanting, and then, when wearied and overcome by the unequal conflict, the exhausted frame gives way, and 'died in the execution of his duty' is the epitaph. Say, is not the conduct of these devoted men as deserving of reward and glory as that of the fiercest leader who ever led a Balaklava charge?"

I am, Sir, yours faithfully,

Pulham Market, Harleston, Norfolk, Walter Pra't'T. 